\title{
PENGGUNAAN METODE LATIHAN TERBIMBING DALAM MENINGKATKAN HASIL BELAJAR SISWA PADA MATERI GERAK PADA TUMBUHAN DI KELAS VIII-1 DI MTs NEGERI LANGSA
}

\author{
Oleh:
}

\author{
LISMAWATI, S.Pd *
}

\begin{abstract}
ABSTRAK
Latar belakang dari penelitian ini adalah belum tuntasnya belajar siswa pada pokok bahasan gerak pada tumbuhan pada siswa kelas VIII.1 MTS Negeri Langsa. Berdasarkan teori belajar, untuk memecahkan masalah tersebut maka peneliti mencoba menerapkan metode latihan terbimbing dalam proses pembelajaran. Adapun tujuan penelitian ini yaitu untuk mengetahui efektivitas metode latihan terbimbing dalam meningkatkan prestasi belajar siswa kelas VIII.1 MTS Negeri Langsa pada materi Gerak pada tumbunhan Tahun Ajaran 2014/2015. Penelitian ini dilaksanakan di MTS Negeri Langsa pada siswa kelas VIII.1 Tahun Ajaran 2014/2015 yang terdiri dari 36 orang Siswa. Penelitian ini adalah Penelitian Tindakan Kelas yang terdiri dari dua siklus. Dari masing-masing siklus diperoleh data berupa hasil observasi dan hasil evaluasi yang dianalisis secara kualitatif dan kuantitatif. Data-data tersebut dikumpulkan dan dikelola dengan indikator yang digunakan, apabila $\geq 85 \%$ dari seluruh siswa telah memperoleh $\geq 75$, maka hipotesis diterima. Dari hasil pengolahan data tersebut, diperoleh persentase ketuntasan belajar pada Siklus I sebesar 61,1 \%, pada Siklus II sebesar 97,2 \%,. Hasil ini menunjukkan adanya peningkatan pada tiap-tiap siklus. Sehingga dapat disimpulkan bahwa dengan penggunaan metode latihan terbimbing dapat meningkatkan Hasil belajar siswa kelas VIII.1 MTs Negeri Langsa pada materi Gerak pada tumbuhan Tahun Ajaran 2014/2015.
\end{abstract}

Keywords : Metode Latihan Terbimbing, Hasil Belajar.

${ }^{*}$ Penulis adalah Guru Madrasah Tsanawiyah Negeri 1 Langsa 


\section{A. Pendahuluan}

Manusia membutuhkan pendidikan dalam kehidupannya. Pendidikan merupakan usaha agar manusia dapat mengembangkan potensi dirinya melalui proses pembelajaran dan atau cara lain yang dikenal dan diakui oleh masyarakat. Sesuai dengan UU RI No. 20 tahun 2003 tentang Sistem Pendidikan Nasional Pasal 3 pendidikan bertujuan untuk mengembangkan potensi peserta didik agar menjadi manusia yang beriman dan bertaqwa kepada Tuhan Yang Maha Esa, berakhlak mulia, sehat, berilmu, cakap, kreatif, mandiri, dan menjadi warga negara yang demokratis serta bertanggung jawab.

Tujuan yang diharapkan ini sulit dicapai apabila siswa dianggap sebagai obyek pembelajaran dengan kegiatan yang mengutamakan pembentukan intelektual dan tidak melatih mereka menjadi insan yang kreatif, mandiri, demokratis serta bertanggung jawab.

Untuk mencapai tujuan di atas, pemerintah telah melakukan pembaharuan melalui pengembangan kurikulum, dari kurikulum lama yang cenderung content based menjadi kurikulum yang berbasis kompetensi (competency based). Sesuai dengan amanat Garis Besar Haluan Negara (GBHN) 1999-2004, Departemen Pendidikan Nasional (Depdiknas) menetapkan kebijakan untuk menyempurnakan kurikulum 1994 menjadi kurikulum 2004 yang telah dilakukan mulai tahun ajaran 2004/2005.

Belajar adalah suatu bentuk pertumbuhan atau perubahan dalam diri seseorang yang dinyatakan dalam cara-cara tingkah laku yang baru, berkat pengalaman dan latihan. Tingkah laku yang baru itu, misalnya dari tidak tahu menjadi tahu, timbulnya pengertian baru, serta timbul dan berkembangnya sifat-sifat sosial, susila, dan emosional (Aqib, 2002:42). ${ }^{2}$

Pada hakekatnya belajar merupakan proses pembentukan hubungan antara stimulus (soal) dan respons (jawab) dan pengulangan terhadap materi untuk memperbesar peluang timbulnya respons benar. Seperti pepatah "latihan menjadikan sempurna" (Edward L. Thordike dalam Dimyati, 2002:46). ${ }^{3}$ Lebih lanjut Thordike mengemukakan beberapa dalil atau hukum yang mengakibatkan munculnya stimulus respons ini, yaitu kesiapan, hukum latihan, dan hukum akibat. Teori tersebut dinamakan teori stimulus respons.

Para guru perlu mengenal cara-cara memotivasi siswa untuk belajar. Motivasi belajar pada mulanya adalah suatu kecenderungan alamiah dalam diri umat manusia, tetapi kemudian terbentuk sedemikian rupa dan secara berangsur-angsur, tidak hanya sekedar menjadi penyebab dan mediatur belajar tetapi juga sebagai hasil belajar itu sendiri (Jaynes, 2004:19). ${ }^{4}$

Pelajaran IPA terkenal menyebalkan dan membosankan. Hal itulah yang menjadi Pekerjaan Rumah (PR) bagi seorang calon guru IPA untuk membuktikan keprofesionalannya bahwa tanggapan semua itu salah.

1 Departemen Pendidikan dan Kebudayaan, 1994. Petunjuk Pelaksanaan Proses Belajar Mengajar, Jakarta. Balai Pustaka. Hal.53

${ }^{2}$ Aqib, 2002. Profesionalisme Guru Dalam Pembelajaran. Surabaya: Insan Cendikia. Hal.42

${ }^{3}$ Dimyati, 2002. Belajar dan Pembelajaran. Jakarta: Rineka Cipta. Hal.46

${ }^{4}$ Jaynes, 2004. Hasrat Untuk Belajar. Jakarta: Pustaka Pelajar. Hal.19 
Sebagai ilmu dasar, IPA seharusnya menjadi suatu pelajaran yang diminati dan disenangi oleh siswa. Namun kenyataannya bahwa rata-rata hasil siswa pada mata pelajaran IPA selalu rendah. Demikian halnya di MTS Negeri Langsa, khususnya siswa kelas VIII.1 yang hasil belajar IPA nya selalu rendah. Hal ini dapat dilihat dari hasil ulangan harian pada setiap pokok bahasan yang menunjukkan tidak tercapainya ketuntasan belajar siswa, yaitu minimal $85 \%$ siswa mendapat nilai minimal 65.

Data di atas menunjukkan bahwa nilai rata-rata siswa pada pokok bahasan gerak pada tumbuhan. Oleh karena itu, guru sebagai manajemen atau pengatur proses belajar mengajar harus memperhatikan hal tersebut. Agar siswa memperoleh pembelajaran yang lebih bermakna, ada beberapa hal yang perlu diperhatikan seperti adanya pembelajaran yang dapat berupa apersepsi atau kegiatan ringan yang menarik. Dalam kegiatan belajar mengajar terdapat perencanaan untuk mengelola perbedaan individual anak dan acuan perbaikan hasil belajar.

Berbicara mengenai pendidikan IPA sebagai salah satu disiplin ilmu yang sangat mendukung kemajuan suatu bangsa, maka haruslah diperjuangkan melalui suatu kegiatan pendidikan. Lebih lanjut Karso (1993:99) berpendapat bahwa IPA merupakan suatu pengetahuan yang mempunyai karakteristik berpikir logis, kritis, sistematis, tekun, kreatif. Diharapkan karakteristik ini dapat diwariskan kepada anak yang mempelajari IPA. ${ }^{5}$

Berdasarkan hal-hal yang telah dikemukakan di atas, maka perlu dilakukan penelitian terkait dengan judul : "penggunaan metode latihan terbimbing dalam meningkatkan hasil belajar siswa pada materi gerak pada tumbuhan di kelas viii1 semester genap di MTs Negeri Langsa tahun ajaran 2014/2015”.

\section{B. Pengertian Hasil Belajar}

Daryanto (1998:456) hasil diartikan sebagai suatu hasil baik yang dicapai dari sebuah proses, seperti halnya dalam proses belajar atau menghasilkan hasil belajar. Hasil belajar adalah perubahan perilaku secara akademik setelah seseorang mengikuti proses pembelajaran. ${ }^{6}$

Dari pengertian tersebut di atas dapat dipahami bahwa belajar terdiri dari beberapa unsur yaitu: unsur objek, unsur transparansi, serta unsur kepandaian, dan unsur latihan.

Unsur objek sebagai sesuatu yang dipelajari yang dapat berupa pengetahuan dan ilmu tertentu, unsur transparansi sebagai jalan untuk memperoleh objek yang dipelajari, unsur kepandaian sebagai hasil aktivitas memperoleh objek yang dijadikan kegiatan belajar, sedangkan unsur latihan sebagai langkah agar apa yang dipelajari dapat mencapai tujuan yang dikehendaki sebelumnya.

Lebih lanjut Daryanto (1998:23) menjelaskan bahwa belajar adalah berusaha memperoleh kepandaian atau ilmu; berlatih; berubah tingkah laku atau tanggapan yang disebabkan oleh pengalaman. ${ }^{7}$ Pengalaman merupakan suatu

\footnotetext{
${ }^{5}$ Karso, 1993. Evaluasi Pendidikan. Surabaya: Usaha Nasional. Hal. 99.

${ }^{6}$ Daryanto, 1998. Kamus Lengkap Bahasa Indonesia. Surabaya: Apollo. Hal. 456.

${ }^{7}$ Ibid, Hal. 23
} 
interaksi, aksi dan reaksi antara individu dengan lingkungannya. Oleh karena itu, belajar akan memberikan hasil yang terbaik jika didasarkan pada pengalaman.

Selain memiliki keempat unsur tersebut, belajar juga memiliki unsur-unsur kegiatan yang meliputi: kegiatan yang menghasilkan penangkapan yang menyangkut apa yang dipelajari, kegiatan yang dapat mengungkapkan mengenai bahan yang dipelajari, dan kegiatan yang membawa tercapainya hal yang dipelajari.

Pengertian yang menyangkut hasil dan belajar dapat diambil suatu perumusan tentang pengertian hasil belajar. Hasil belajar pada dasarnya adalah:

1. Hasil yang dicapai dalam menuntut ilmu pengetahuan.

2. Hasil yang dicapai dalam menambah dan mengumpulkan sejumlah ilmu pengetahuan.

3. Hasil yang dicapai dalam wujud perubahan tingkah laku seseorang akibat pengaruh usaha pendidikan.

4. Hasil yang dicapai dalam pengorganisasian pengalaman-pengalaman masa lampau atau terdahulu yang belum sempurna.

Pengertian di atas dapat disimpulkan bahwa yang dimaksud dengan hasil belajar siswa melalui pemberian latihan dalam pengajaran pokok bahasan gerak pada tumbuhan adalah hasil yang dicapai siswa setelah menyelesaikan soal-soal yang telah diberikan setelah pengajaran pokok bahasan selesai diajarkan.

\section{Faktor-Faktor yang Mempengaruhi hasil Belajar}

Slameto (2003:54-60), mengatakan bahwa Hasil belajar siswa pada umumnya dipengaruhi oleh dua faktor, yaitu faktor yang berasal dari dalam individu (faktor internal), dan faktor yang berasal dari luar individu (faktor eksternal). ${ }^{8}$

\section{Faktor Internal}

\section{a. Faktor Jasmaniah}

Faktor jasmaniah meliputi faktor kesehatan dan cacat tubuh. Sehat berarti dalam keadaan baik segenap badan dan bebas dari penyakit. Kesehatan seseorang berpengaruh terhadap belajarnya. Sedangkan cacat tubuh itu dapat berupa buta, tuli, lumpuh, dan lain-lain. Keadaan cacat tubuh juga bisa mempengaruhi belajar. Siswa yang cacat tubuh, maka belajarnya juga akan terganggu.

\section{b. Faktor Psikologis}

Faktor Psikologis meliputi inteligensi, perhatian, minat, bakat, motif, serta kematangan, dan kesiapan. Faktor inteligensi atau kecerdasan besar pengaruhnya terhadap kemajuan belajar, karena hal ini menentukan kemampuan siswa dalam menyerap ilmu pengetahuan yang dipelajarinya. Kemudian perhatian juga dapat menjamin hasil belajar yang baik, sehingga siswa harus mempunyai perhatian terhadap bahan yang dipelajarinya. Dan juga hasil belajar siswa ini dapat dipengaruhi oleh faktor minat dan bakat. Kemampuan itu baru akan terealisasi menjadi kecakapan yang nyata sesudah belajar atau berlatih.

Faktor motif erat sekali hubungannya dengan tujuan yang akan dicapai. Dalam proses belajar haruslah diperhatikan apa yang mendorong

\footnotetext{
${ }^{8}$ Slameto, 2003. Belajar dan Faktor-Faktor yang Mempengaruhinya. Jakarta: Rineka Cipta.
} 
siswa agar dapat belajar dengan baik atau mempunyai motif untuk berpikir. Motif-motif ini ditanamkan kepada diri siswa dengan cara memberikan latihan-latihan atau kebiasaan-kebiasaan. Sedangkan kematangan adalah suatu tingkat dalam pertumbuhan seseorang. Kematangan belum berarti anak dapat melaksanakan kegiatan secara terus-menerus, untuk itu diperlukan latihan-latihan dalam pelajaran. Kemudian faktor kesiapan juga perlu diperhatikan dalam proses belajar, karena jika siswa sudah ada kesiapan, maka hasil belajarnya akan lebih baik.

\section{c. Faktor Kelelahan}

Faktor Kelelahan meliputi kelelahan jasmani dan kelelahan rohani. Kelelahan jasmani terjadi karena adanya kekacauan substansi sisa pembakaran di dalam tubuh. Sedangkan kelelahan rohani ini dapat dilihat dengan adanya kelesuan dan kebosanan.

\section{Faktor Eksternal}

\section{a. Faktor Keluarga}

Siswa yang belajar akan menerima pengaruh dari keluarga berupa: cara orang tua mendidik, relasi antar-anggota keluarga, suasana rumah tangga, keadaan ekonomi keluarga, dan pengertian orang tua.

\section{b. Faktor Sekolah}

Faktor sekolah yang mempengaruhi belajar ini mencakup metode mengajar, disiplin sekolah, serta pelajaran dan waktu.

\section{c. Faktor Masyarakat}

Masyarakat merupakan faktor yang juga berpengaruh terhadap belajar siswa. Pengaruh ini terjadi karena keberadaan siswa dalam masyarakat.

\section{Belajar Mengajar}

Belajar ditandai dengan adanya perubahan tingkah laku sebagai hasil pengalaman yang bersifat tahan lama dan bukan sebagai hasil dari proses pertumbuhan (Soeharto, 2003:108). ${ }^{9}$ Belajar merupakan suatu perubahan tingkah laku yang relatif menetap sebagai hasil dari latihan atau pengalaman.

Belajar IPA memerlukan pemahaman konsep-konsep. Memahami konsep IPA perlu pula memperhatikan konsep-konsep sebelumnya. Ini berarti belajar IPA harus bertahap dan berurutan secara sistematis serta harus didasarkan kepada pengalaman. Mempelajari materi-materi IPA, tidak cukup hanya dipelajari dengan membacanya saja. Untuk dapat memahaminya memerlukan waktu dan latihan.

Berdasarkan uraian di atas, maka guru dituntut untuk lebih aktif melatih cara berpikir siswa, diantaranya dengan memberikan latihan-latihan menyelesaikan soal-soal dari konsep-konsep yang pernah dipelajarinya. Dalam hal ini hasil belajar dikhususkan untuk pelajaran IPA. Tentang kemampuan untuk menyelesaikan soalsoal yang diupayakan peningkatannya, melalui latihan-latihan menyelesaikan soalsoal yang ada hubungannya dengan pokok bahasan gerak pada tumbuhan.

\footnotetext{
${ }^{9}$ Soeharto, 2003. Teknologi Pembelajaran. Surabaya: SIC (Surabaya Intellectual Club).
} Hal. 108 


\section{E. Metode Latihan Terbimbing}

Metode latihan merupakan metode yang memberikan kesempatan kepada siswa untuk berlatih memberikan suatu keterampilan yang tertentu. Terbimbing di sini artinya proses belajar mengajar yang dibimbing berdasarkan petunjuk dan penjelasan guru. Melalui metode ini dapat dikembangkan keterampilan melalui pembiasaan (Aqib, 2002:97). ${ }^{10}$ Mengingat latihan ini kurang mengembangkan bakat atau inisiatif siswa untuk berpikir, maka latihan untuk pertama kalinya hendaknya bersifat diagnosis, pada mulanya kurang berhasil, lalu diadakan perbaikan untuk kemudian bisa menjadi sempurna (Sudjana, 2000:87). ${ }^{11}$

Untuk meningkatkan hasil belajar maka akan dicoba dengan menggunakan model kooperatif, adalah sistem belajar mengajar dengan menekankan keaktifan siswa secara fisik, mental, intelektual dan emosional untuk memperoleh hasil belajar secara berkelompok.

\section{Langkah-Langkah Metode Latihan}

Langkah-langkah metode latihan antara lain:

a. Dalam pelaksanaan latihan hendaknya guru memberikan bimbingan kepada siswa yang mengalami kesulitan atau salah arah dalam menyelesaikan soal.

b. Latihan tidak perlu lama asal sering dilaksanakan.

c. Harus disesuaikan dengan taraf kemampuan siswa.

d. Memberikan dorongan terutama bagi siswa lambat atau kurang bergairah mengerjakan latihan.

e. Guru memberikan penilaian untuk memotivasi belajar siswa.

\section{Kelebihan dan Kelemahan Metode Latihan}

Metode latihan memiliki kelebihan dan kelemahan (Sagala, 2005:

217-218), yaitu:

Kelebihannya antara lain:

a. Pembentukan kebiasaan yang dilakukan dengan menggunakan metode ini akan menambah ketepatan dan kecepatan pelaksanaan.

b. Pemanfaatan kebiasaan-kebiasaan tidak memerlukan banyak kosentrasi dalam pelaksanaannya.

c. Pembentukan kebiasaan membuat gerakan-gerakan yang kompleks, rumit menjadi otomatis.

Kelemahannya antara lain:

a. Metode ini dapat menghambat bakat dan inisiatif siswa.

b. Kadang-kadang latihan yang dilaksanakan secara berulang-ulang merupakan hal yang monoton, mudah membosankan.

c. Membentuk kebiasaan yang kaku, karena siswa lebih banyak ditujukan untuk mendapatkan kecakapan memberikan respons secara otomatis, tanpa menggunakan intelegensi.

d. Dapat menimbulkan verbalisme karena siswa lebih banyak dilatih menghafal soal-soal dan menjawabnya secara otomatis.

\footnotetext{
${ }^{10}$ Opcit., hal. 97.

${ }^{11}$ Sudjana, 2000. Dasar-Dasar Proses Belajar Mengajar. Bandung: Sinar Baru Algensindo.
} hal. 87 . 
Cara-cara mengatasi kelemahan metode latihan antara lain:

a. Latihan hanya untuk bahan atau tindakan yang bersifat otomatis.

b. Latihan harus memiliki arti yang luas.

c. Masa latihan relatif harus singkat, tetapi harus sering dilakukan pada waktu lain.

d. Latihan harus menarik, gembira, dan tidak membosankan.

e. Proses latihan dan kebutuhan harus disesuaikan dengan proses perbedaan individual.

\section{F. METODE PENELITIAN}

\section{Setting Penelitian}

Penelitian ini dilaksanakan selama 3 bulan dengan menggunakan hari-hari efektif sesuai dengan waktu proses belajar mengajar. Penelitian dilaksanakan dalam dua siklus yang setiap siklus dua kali pertemuan. Siklus I pertemuan pertama di laksanakan pada tanggal 9 Februari 2015 dan pertemuan kedua dilaksanakan pada tanggal 23 februari 2015. Siklus dua pertemuan pertama di laksanakan pada tanggal 2 maret 2015 dan pertemuan kedua dilaksanakan pada 9 maret 2015. Penelitian ini dilakukan di kelas VIII-1 pada MTsN Langsa. Subjek penelitian ini adalah siswa kelas VIII-1 pada MTsN Langsa tahun pelajaran 2014/2015 yang terdiri dari 36 orang siswa.

\section{Prosedur Penelitian}

Penelitian ini merupakan penelitian tindakan kelas (Action Recearch). Menurut Tim Pelatihan PGSM (1999:6) penelitian tindakan kelas didefinisikan sebagai suatu bentuk kajian yang bersifat reflektif oleh pelaku tindakan yang dilakukan untuk meningkatkan kemampuan rasional dari tindakan-tindakan mereka dalam melaksanakan tugas, memperdalam pemahaman terhadap tindakan-tindakan yang dilakukannya itu, serta memperbaiki kondisi di mana praktek-praktek pembelajaran tersebut dilakukan. Untuk mewujudkan tujuan-tujuan tersebut, penelitian tindakan kelas itu dilaksanakan berupa proses pengkajian berdaur (Cyclical) yang terdiri dari 4 tahap.

Adapun keempat tahapan pelaksanaan penelitian tindakan kelas adalah (Action Recearch) sebagai berikut:

a. Rencana : Tindakan apa yang akan dilakukan untuk memperbaiki, meningkatkan atau perubahan perilaku dan sikap sebagai solusi.

b. Tindakan : Apa yang dilakukan oleh guru atau peneliti sebagai upaya perbaikan, peningkatan atau perubahan yang diinginkan.

c. Observasi : Mengamati atas hasil atau dampak dari tindakan yang dilaksanakan atau dikenakan terhadap siswa.

d. Refleksi : Peneliti mengkaji, melihat dan mempertimbangkan atas hasil atau dampak dari tindakan dari berbagai kriteria.

Dari pendapat di atas, maka inti dari penelitian tindakan adalah adanya tindakan untuk meningkatkan atau memperbaiki kualitas pelaksanaan KBM yang lebih baik. Langkah-langkah pelaksanaan tindakan meliputi keempat komponen yang telah disebutkan di atas dan berlangsung secara siklus, yaitu rencana-tindakan- 
observasi-refleksi dan seterusnya seperti pada gambar, sehingga tercapai tujuan yang diinginkan dengan tindakan yang paling efektif.

Kegiatan penelitian ini meliputi tiga tahap, yaitu perencanaan, pelaksanaan dan analisis data. Kegiatan yang dilakukan pada tahap perencanaan adalah menyusun/menyiapkan materi pelajaran, menyusun instrument data dan menyusun rencana pembelajaran
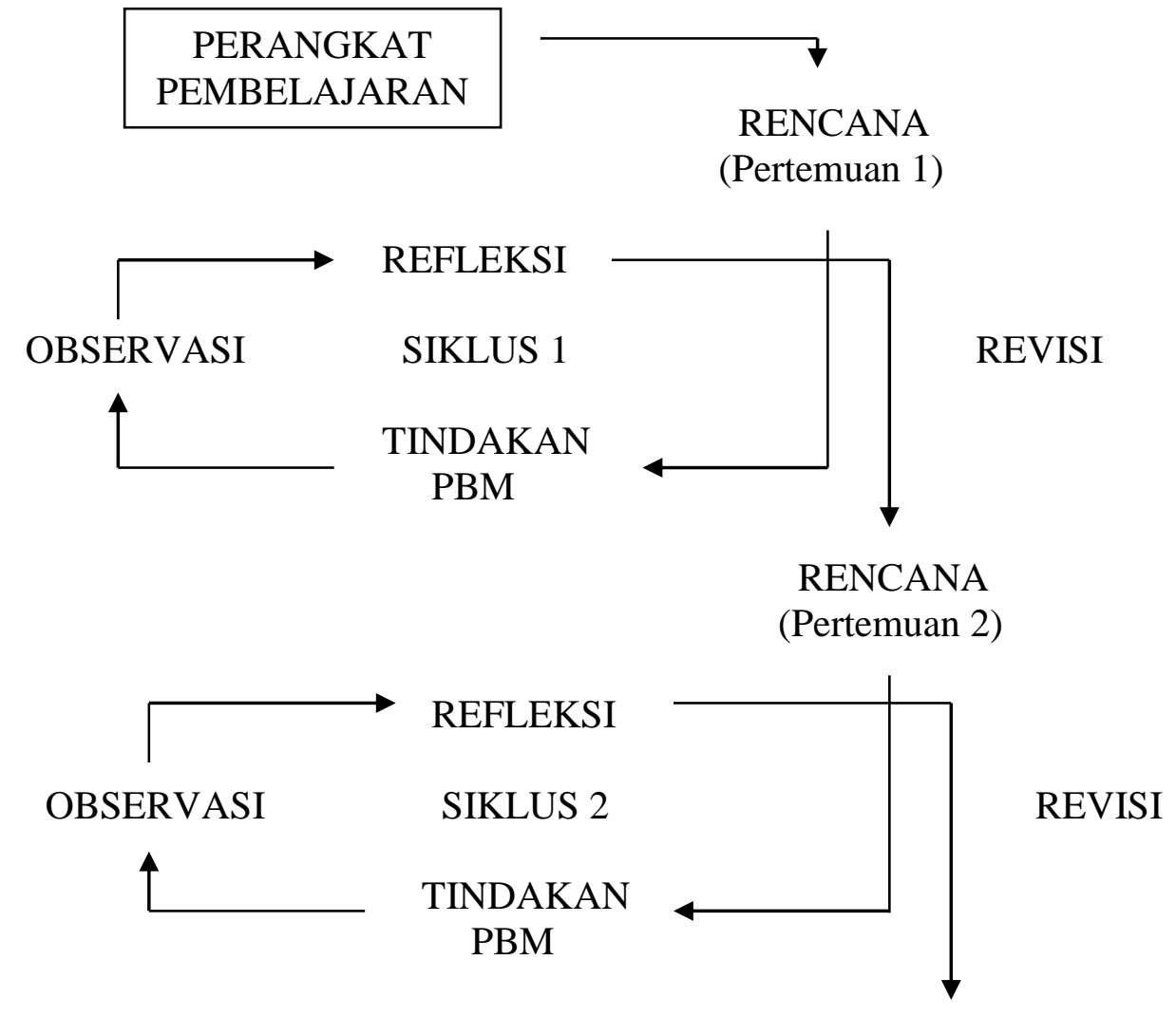

\section{Indikator Kinerja}

Dalam penelitian ini yang akan dilihat indikator kinerjanya. Penulisan rangkuman siswa adalah guru, karena guru merupakan fasilitator yang sangat berpengaruh terhadap kinerja siswa.

a. Rata - rata hasil test ulangan harian 65 indikator kinerja menjadi 75.

b. Penilaian hasil observasi tentang keaktifan siswa dalam proses pembelajaran IPA.

\section{Teknik dan Alat Pengumpulan Data}

Dalam penelitian ini pengumpulan data menggunakan teknik tes dan non tes. Tes tertulis digunakan pada akhir siklus I dan akhir siklus II. Teknik non tes meliputi teknik observasi dan dokumentasi. Observasi digunakan pada saat pelaksanaan penelitian tindakan kelas. Kemampuan memahami materi gerak pada tumbuhan pada siklus I, II. Sedangkan Teknik Dokumentasi dikumpulkan dari hasil kehadiran dan kerajinan siswa. 


\section{G. Teknik Analisis Data}

Analisis data yang digunakan dalam penelitian ini adalah teknik analisis deskriptif yang meliputi :

1. Analisis deskriptif komparatif, hasil belajar dengan cara membandingkan hasil belajar pada siklus I, II dan membandingkan hasil belajar dengan indikator pada siklus I, II .

2. Analisis deskriptif kualitatif, hasil observasi dengan cara membandingkan hasil observasi dan refleksi pada siklus I, II .

Menurut Milas (1992:16) data yang sudah terkumpul dianalisis dengan mempedomani langkah-langkah analisis data penelitian kualitatif, analisis berlangsung dengan tiga jalur kegiatan yang terjadi secara bersamaan yaitu:

1. Reduksi data, yaitu meliputi proses penyeleksian, pemilihan, penyederhanaan dan pengkatagorian data, menganalisis dan penarikan kesimpulan.

2. Pengujian data, yaitu dengan mendeskripsikan apa yang terjadi

3. Penarikan kesimpulan yang dilakukan sejak tahap pengumpulan data dengan cara mencatat pada buku penelitian. ${ }^{12}$

\section{H. Hasil Penelitian}

\section{Deskripsi Kondisi Awal}

Pembelajaran pada kondisi awal, dari 36 jumlah siswa kelas VIII-1 hanya 1 siswa $(2,77 \%)$ yang tuntas, sedangkan sisanya sebanyak 35 siswa $(97,23 \%)$ tidak tuntas. Berdasarkan pada kegiatan kondisi awal, peneliti melakukan refleksi dari hasil kegiatan tersebut.

Pada kondisi awal didapatkan masih banyak siswa yang belum memahami materi gerak pada tumbuhan. Bertolak dari kondisi di atas, maka perlu adanya perubahan cara menyampaikan materi pelajaran. Untuk itulah maka peneliti menggunakan metode Latihan Terbimbing untuk meningkatkan hasil belajar siswa.

\section{Hasil Penelitian Siklus I}

Berdasarkan hasil penelitian pada siklus I diperoleh nilai siswa yang berhasil tuntas sesuai dengan kriteria ketuntasan minimal (KKM 75), 22 siswa ( 61,1\%) yang tuntas dan 14 siswa ( 38,9 \% ) tidak tuntas. Hal ini terjadi karena masih banyak siswa yang belum begitu memahami cara-cara melakukan kegiatan dengan menggunakan metode Latihan Terbimbing dengan menggunakan peta konsep serta siswa masih enggan untuk bertanya kepada guru penulisan rangkuman sehingga waktu banyak tidak efektif sesuai dengan apa yang direncanakan.

Berdasarkan hasil observasi peneliti dan pengamat atas hasil kemampuan siswa, maka peneliti dan pengamat kembali merencanakan untuk melanjutkan pada tindakan siklus II dengan terlebih dahulu melakukan perbaikan. Dengan demikian, maka direncanakan pada Siklus II ini penggunaan metode metode Latihan Terbimbing dilaksanakan lebih terarah lagi supaya hasil dicapai juga lebih optimal.

${ }^{12}$ Milas, 1992. Metodologi Penelitian Pendidikan. Surabaya: SIC (Surabaya Intellectual Club), hal. 16. 


\section{Hasil Penelitian Siklus II}

Pada Siklus II, kemampuan siswa mengalami peningkatan, jumlah siswa yang tuntas meningkat yaitu sebanyak 35 siswa $(97,2 \%)$ sedangkan yang tidak tuntas hanya 1 siswa (2,8 \%). Hasil tersebut mengindikasikan bahwa rasa takut salah dan malu untuk bertanya sudah berkurang. Siswa sudah mulai mau berbagi kepada teman-temannya. Bahkan mereka juga sudah berani mengajukan saran atau mengomentari pendapat temannya yang keliru. Kalau diperhatikan tiap aktivitas, memang peningkatannya tidak seberapa besar. Tetapi kalau dilihat dari pengelompokan partisipasi aktif dan pasif, prosentase tersebut cukup besar.Agar lebih jelas gambaran perbandingan peningkatan hasil kemampuan dari kondisi awal, Siklus I dan Siklus II, dapat dilihat dan diperhatikan pada rekapitulasi tabel dan grafik di bawah ini.

Tabel Rekapitulasi Ketuntasan Belajar Setiap Siklus

\begin{tabular}{|c|c|c|c|c|c|c|c|c|c|c|}
\hline \multirow[t]{2}{*}{ NO } & \multirow[t]{2}{*}{ KRITERIA } & \multicolumn{3}{|c|}{ KONDISI AWAL } & \multicolumn{3}{|c|}{ SIKLUS I } & \multicolumn{3}{|c|}{ SIKLUS II } \\
\hline & & JLH & KATEGORI & $\%$ & JLH & KATEGORI & $\%$ & JLH & KATEGORI & $\%$ \\
\hline 1 & NILAI $\geq 75$ & 1 & $\mathrm{~T}$ & 2,77 & 22 & $\mathrm{~T}$ & 61,1 & 35 & $\mathrm{~T}$ & 97,2 \\
\hline 2 & NILAI $\leq 75$ & 35 & TT & 97,23 & 14 & TT & 38,9 & 1 & TT & 2,8 \\
\hline & JUMLAH & 36 & & 100 & 36 & & 100 & 36 & & 100 \\
\hline
\end{tabular}

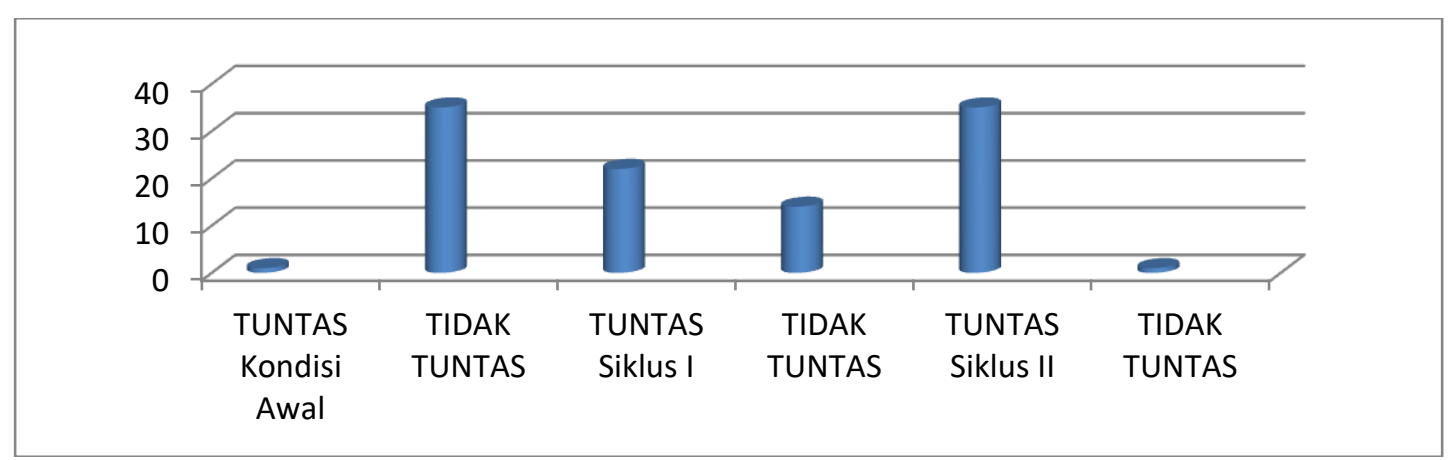

Berdasarkan data rekapitulasi perbandingan pada tabel dan grafik di atas, diketahui bahwa pada kondisi awal siswa kelas VIII-1 yang tuntas hanya 1 siswa $(2,77 \%)$ dan yang tidak tuntas sebanyak 35 siswa $(97,23 \%)$. Sedangkan pada Siklus I siswa yang tuntas mengalami peningkatan menjadi 22 siswa $(61,1 \%)$, dan yang tidak tuntas berkurang menjadi 14 siswa $(38,9 \%)$. Pada Siklus II kembali meningkat yaitu sebanyak sebanyak 35 siswa $(97,2 \%)$ tuntas, sedangkan yang tidak tuntas hanya 1 siswa $(2,8 \%)$.

Disamping ketuntasan belajar, nilai rata-rata siswa juga meningkat pada setiap siklusnya, hal ini dapat dilihat pada rekapitulasi nilai tes siswa pada tabel dan grafik berikut : 
Tabel Rekapitulasi Nilai Tes Setiap Siklus

\begin{tabular}{|l|c|c|c|}
\hline \multirow{2}{*}{ KETERANGAN } & \multicolumn{3}{|c|}{ NILAI } \\
\cline { 2 - 4 } & $\begin{array}{c}\text { KONDISI } \\
\text { AWAL }\end{array}$ & $\begin{array}{c}\text { SIKLUS } \\
\text { I }\end{array}$ & $\begin{array}{c}\text { SIKLUS } \\
\text { I }\end{array}$ \\
\hline NILAI TERTINGGI & 77 & 80 & 90 \\
\hline NILAI TERENDAH & 50 & 60 & 70 \\
\hline JUMLAH NILAI & 1925 & 2525 & 3120 \\
\hline NILAI RATA-RATA & 53,5 & 70.10 & 86,7 \\
\hline
\end{tabular}

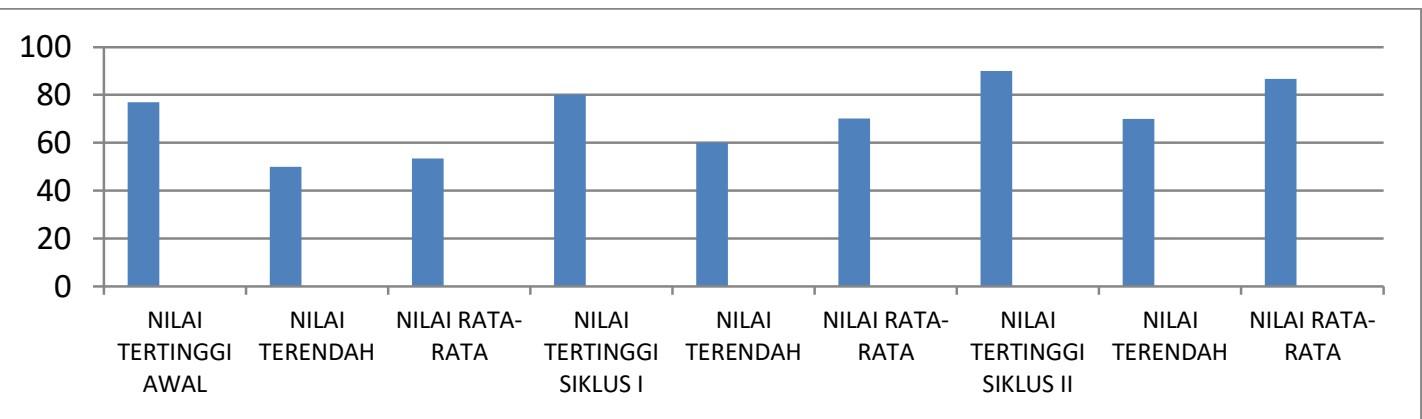

Gambar Grafik Rekapitulasi Nilai Tes Setiap Siklus

Data rekapitulasi perbandingan pada tabel dan grafik di atas menunjukkan bahwa pada kondisi awal nilai tertinggi hanya 77 dan nilai terendah 50 dengan nilai rata-rata hanya sebesar 53,5. Sedangkan pada Siklus I nilai tertinggi 80 dan nilai terendah 60 dengan nilai rata-rata mencapai 70,10. Pada Siklus II nilai tertinggi mencapai 90 sedangkan nilai terendah 70 dengan nilai rata-rata mencapai 86,7.

\section{Kesimpulan}

Berdasarkan hasil penelitian dapat ditarik kesimpulan penerapan metode Latihan Terbimbing dengan menggunakan peta konsep dapat meningkatkan hasil belajar siswa materi gerak pada tumbuhan di kelas VIII-1 semester II MTs Negeri Langsa Tahun Ajaran 2014/2015, peningkatan hasil belajar terjadi karena guru menggunakan metode Latihan Terbimbing dengan menggunakan peta konsep dalam menyajikan materi gerak pada tumbuhan dalam penyusunan rencana pelaksanaan pembelajaran. Dengan menggunakan metode Latihan Terbimbing dengan menggunakan peta konsep materi yang ingin dipelajari siswa tidak hanya dilihat dan didengar tapi lebih dari itu, siswa mampu melakukan kegiatan dan melihat sendiri yang sering mereka baca dan lihat pada buku pelajaran. Dengan melakukan kegiatan siswa menjadi tidak pasif serta materi mudah diingat selain itu belajar menjadi menyenangkan.

\section{DAFTAR PUSTAKA}

Aqib, 2002. Profesionalisme Guru Dalam Pembelajaran. Surabaya: Insan Cendikia. Daryanto, 1998. Kamus Lengkap Bahasa Indonesia. Surabaya: Apollo.

Departemen Pendidikan dan Kebudayaan, 1994. Petunjuk Pelaksanaan Proses Belajar Mengajar, Jakarta. Balai Pustaka.

Dimyati, 2002. Belajar dan Pembelajaran. Jakarta: Rineka Cipta. 
Jaynes, 2004. Hasrat Untuk Belajar. Jakarta: Pustaka Pelajar.

Karso, 1993. Evaluasi Pendidikan. Surabaya: Usaha Nasional.

Milas, 1992. Metodologi Penelitian Pendidikan. Surabaya: SIC (Surabaya Intellectual Club).

Sagala, 2005. Konsep dan Makna Pembelajaran. Bandung: Alfabeta.

Slameto, 2003. Belajar dan Faktor-Faktor yang Mempengaruhinya. Jakarta: Rineka Cipta.

Soeharto, 2003. Teknologi Pembelajaran. Surabaya: SIC (Surabaya Intellectual Club).

Sudjana, 2000. Dasar-Dasar Proses Belajar Mengajar. Bandung: Sinar Baru Algensindo.

Team Pelatih PGSM, 1999. Penelitian Tindakan Kelas. Jakarta: DepDikNas. 